\title{
Plasma Growth Hormone Concentration in Corticosteroid-Treated Children
}

\author{
Helen G. Morris, Jacqueline R. Jorgensen, and Shirley A. Jenkins \\ From the Department of Medicine, Veterans Administration Hospital, \\ University of Colorado School of Medicine, and Children's Asthma \\ Research Institute and Hospital, Denver, Colorado
}

A B S T R A C T Endogenous plasma growth hormone concentrations were measured in 23 children who were receiving daily corticosteroid therapy and in 10 control asthmatic children who had not received steroids for at least 8 months. The growth hormone concentrations were similar in the two groups of patients both during the fasting state and after insulin-induced hypoglycemia. 12 children, who were studied while receiving a large dose of prednisone and again 2 wk after steroid withdrawal, also showed no change in growth hormone concentration in relation to corticosteroid therapy. These findings suggest that deficiency of growth hormone is not the major mechanism responsible for the dwarfism of corticosteroidtreated children.

\section{INTRODUCTION}

The mechanisms responsible for growth retardation in children given prolonged corticosteroid therapy have not been defined. Previous studies in this laboratory have demonstrated that corticosteroid-treated children have impaired metabolic response to acute administration of human growth hormone $(\mathrm{HGH})$ and show no improvement in their retarded rate of growth during prolonged HGH administration (1). These observations have suggested that the mechanism responsible for the growth retardation might be due to corticosteroid-induced antagonism of the effects of

A preliminary report of this work was presented in part in Clin. Res. April 1966.

Address requests for reprints to Dr. Helen G. Morris, 1055 Clermont Street, Denver, Colo. 80220.

Received for publication 7 November 1966 and in revised form 21 September 1967.
$\mathrm{HGH}$ at the tissue level. On the other hand, Frantz and Rabkin and Hartog, Gaafar, and Fraser have reported that corticosteroid-treated adults show inhibition of pituitary release of $\mathrm{GH}$ after hypoglycemia $(2,3)$ and have postulated that dwarfism in steroid-treated children might be due in part to relative deficiency of endogenous GH (2). The present study was undertaken to determine plasma growth hormone levels in relation to corticosteroid treatment in a relatively homogeneous population of children who suffer from asthma. Plasma growth hormone levels in steroid-treated children during the fasting state and after induced hypoglycemia were compared with those observed in nonsteroid-treated asthmatic control children. Many of the children were studied both during corticosteroid administration and after total withdrawal of steroids.

\section{METHODS}

Patient population. Studies were performed on 33 children, aged 8-15, who were resident patients of the Children's Asthma Research Institute and Hospital (CARIH). 10 control asthmatic children had received no corticosteroid for at least 8 months. 23 children had received daily corticosteroid for prolonged periods with therapy at the dose indicated for at least 1 month. 11 of the children required maintenance with stable doses of steroid (prednisone $2.5-30 \mathrm{mg} /$ day). 12 children were able to tolerate total discontinuation of steroid and were studied while receiving a large dose of prednisone (10$15 \mathrm{mg} /$ day) and again $2 \mathrm{wk}$ after steroid withdrawal. Some of the patients in the last group were studied on several occasions as steroid dose was being reduced (by $2.5 \mathrm{mg}$ every 10 days) and at intervals after discontinuation of steroid. The sex distribution of the population at CARIH is reflected in our study, with the steroidtreated group containing a larger percentage of males and the nonsteroid group containing a higher percentage of females. 
Study protocol. All studies were performed on fasting subjects who had been at bed rest for at least $2 \mathrm{hr}$. Most of the children receiving corticosteroid had their usual morning dose of prednisone withheld until completion of the test. After initial venipuncture, an intravenous infusion of normal saline was begun and continued throughout the study. All subsequent blood samples were obtained through the infusion needle after the first few drops of blood were discarded to minimize dilution error. Two control samples were obtained for glucose and GH determinations. Crystalline insulin was then administered intravenously at a dose of $0.1 \mathrm{U} / \mathrm{kg}$ of body weight. Repeat samples for glucose determination were obtained $20,30,45$, 60,90 , and $120 \mathrm{~min}$ after insulin administration. Repeat samples for $\mathrm{GH}$ determination were obtained $30,60,90$, and $120 \mathrm{~min}$ after insulin administration. Some studies were terminated before $120 \mathrm{~min}$ because of persisting hypoglycemia.

A physician remained in the room continously throughout each insulin tolerance test. Glucagon and $50 \%$ glucose were immediately available to counteract hypoglycemia if this seemed indicated. At the termination of the study, children were given sweetened juice and were fed. Close observation was continued for several hours.

Methods of analysis. Samples for blood glucose were collected in tubes containing sodium fluoride and were analyzed by either the glucostat method (4) or by the AutoAnalyzer (5). The values reported are the fasting sugars, the minimum blood sugars (obtained at either 20 or $30 \mathrm{~min}$ after insulin administration), and the $60-\mathrm{min}$ values.

Samples for GH were collected in heparinized tubes, kept in an ice bath until separated in a refrigerated centrifuge, and then stored in a freezer. $\mathrm{GH}$ concentration was determined by the radioimmunoassay method of Glick, Roth, Yalow, and Berson (6). Most of the plasma samples were assayed on several occasions, and the value shown is the mean of all determinations. The $\mathrm{GH}$ values reported are those observed during the fasting state and $60 \mathrm{~min}$ after insulin administration. The $60 \mathrm{~min}$ sample was selected as the indicator of response to hypoglycemia, since this value was determined in all patients studied and in most subjects was the highest value observed. Glucose and $\mathrm{GH}$ results obtained in the different groups of children were analyzed by Student's $t$ test (7).

Immunoassay method. ${ }^{131}$ I-labeled HGH (specific activity $300-500 \mu \mathrm{c} / \mu \mathrm{g}$ ) was prepared by the method of Greenwood, Hunter, and Glover (8) using $5 \mu \mathrm{g}$ of $\mathrm{HGH}$ (Wilhelmi HS 612B), 2-3 mc of ${ }^{131}$ I (Iso-Serve, Cambridge Nuclear Corp., Cambridge, Mass.), and 44 $\mu \mathrm{g}$ of chloramine- $\mathrm{T}$ for $1 \mathrm{~min}$, followed by $120 \mu \mathrm{g}$ of sodium metabisulfite. The labeled fraction containing the least amount of damage after purification (starch gel electrophoresis (9) or filtration through a Sephadex G-100 column (10)) was identified by paper chromatoelectrophoresis (11) and was used in the assay after dilution to $60,000 \mathrm{cpm}$. Antiserum prepared in rabbits using Elrick HGH (E-20) (12) was adsorbed by precipitation with lyophilized, pooled human serum to remove possible antibody to human serum components and was used in the assay at a final concentration of $1: 130,000$.
Standard curves were prepared for each immunoassay run using either Wilhelmi GH (HS 612B) or the British Medical Research Council (MRC) "GH assay standard A" which gave identical slopes. ${ }^{1}$ Unknown samples were calculated on the basis of the MRC standard. Each plasma sample was assayed in duplicate at three different dilutions, with one tube in each set of three serving as a control tube. $0.1 \mathrm{ml}$ of plasma or diluted plasma was used in the incubate. All solutions were prepared with Veronal buffer 0.1 mole/liter, $\mathrm{pH} 8.6$, containing $1 \%$ normal rabbit serum and $2.5 \mathrm{mg} / \mathrm{ml}$ of human serum albumin (The Cutter Laboratories, Berkeley, Calif.). Tubes containing either standards or plasma samples were incubated with labeled $\mathrm{GH}{ }^{131} \mathrm{I}$ and antiserum in a final volume of $1 \mathrm{ml}$ for 4-8 days at $5^{\circ} \mathrm{C}$. A $0.2 \mathrm{ml}$ aliquot of the incubate (and $0.02 \mathrm{ml}$ of pooled human serum for carrier protein in incubates containing standards or diluted plasma specimens) were then applied to $1 \frac{1}{4}$-inch wide strips of Whatman $3 \mathrm{MC}$ chromatographic paper and subjected to chromatoelectrophoresis at $30 \mathrm{v} / \mathrm{strip}$ for $45 \mathrm{~min}$ at room temperature, which separated the radioactive label into a free peak (F) and an antibody-bound peak (B). Paper strips were oven-dried and then scanned for radioactivity at the rate of $2 \mathrm{~cm} / \mathrm{min}$ in an automatic 4 pi radiochromatograph scanner equipped with an integrator recorder. The integrator excursions were used to determine the areas under radioactivity peaks.

Standard curves were plotted either on linear graph paper as $\mathrm{B} / \mathrm{F}$ ratio vs. concentration of $\mathrm{HGH}$ in millimicrograms per milliliter, according to the method of Berson-Yalow (11), which gave the curve shown in Fig. 1, or were plotted on semilogarithmic paper as per cent bound vs. $\log \mathrm{GH}$ concentration which gave the linear relationship shown in Fig. 2. The latter plot was found to be more convenient for estimating the $\mathrm{GH}$ concentration of unknown plasma samples.

Precision of the immunoassay. Since the GH values reported here were obtained by duplicate determinations at several dilutions and in most instances were analyzed on several occasions, the results obtained with these plasma samples were used to estimate the precision of the immunoassay in our hands. The mean difference in per cent of radioactivity in the bound fraction in $\mathbf{4 0 0}$ duplicate determinations (at various dilutions) was $\pm 3 \%$. In terms of millimicrograms per milliliter of $\mathrm{GH}$, comparison of 182 duplicate determinations which yielded measurable $\mathrm{GH}$ values showed a mean difference of $\pm 22 \%$. The precision at various ranges of GH concentration shown in Table $I$ is similar to that reported for $\mathrm{GH}$ immunoassay by other investigators (13-15). Comparison of the results obtained when 148 specimens were analyzed at two different dilutions indicated a slight but significantly greater value at the higher dilution. Comparison of the results observed when 115 specimens were analyzed on different occasions yielded no significant differences.

$1 \mathrm{We}$ are indebted to Dr. A. E. Wilhelmi (National Pituitary Agency) and Dr. D. Bangham (British Medical Research Council) for providing the purified GH preparations used for assay standards. 


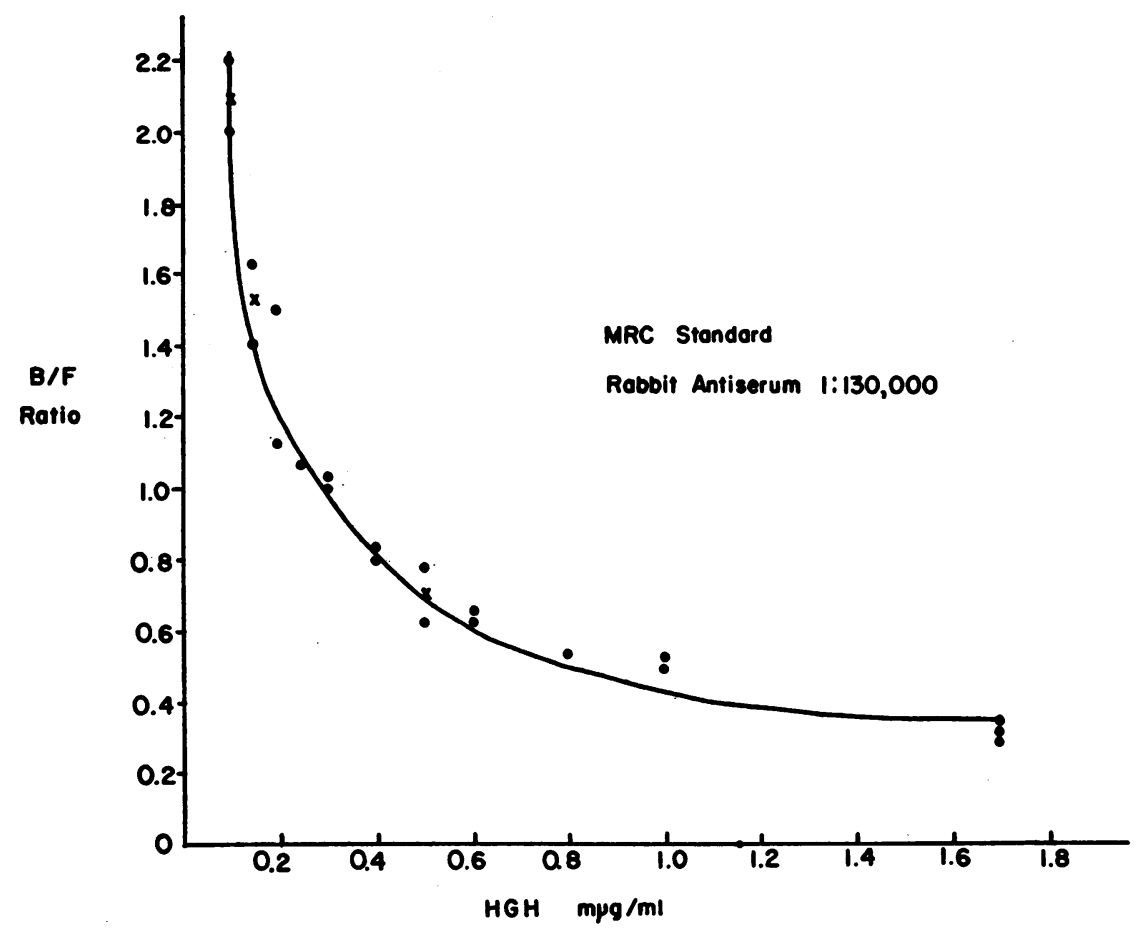

FIGURE 1 Growth hormone immunoassay standard curve (2/9/66). The results are plotted as antibody-bound peak/free peak ratio (B/F ratio) vs. $\mathrm{GH}$ concentration $(\mathrm{m} \mu \mathrm{g} / \mathrm{ml})$.

\section{RESULTS}

We found that induction of hypoglycemia for the purpose of measuring plasma $\mathrm{GH}$ concentrations was a safe procedure in the asthmatic children. A single, potentially serious reaction was encountered when one child developed CheyneStokes respirations $30 \mathrm{~min}$ after insulin administration with a blood glucose concentration of 25 $\mathrm{mg} / 100 \mathrm{ml}$. He was immediately given intravenous glucose and recovered promptly; subsequent observation revealed no sequellae. Not one acute episode of asthma occurred during the conduct of

TABLE I

Precision of GH Immunoassay

\begin{tabular}{cccc}
\hline $\begin{array}{c}\text { Range GH } \\
\text { concentration }\end{array}$ & $\begin{array}{c}\text { No. of } \\
\text { samples }\end{array}$ & $\begin{array}{c}\text { Mean GH } \\
\text { concentration }\end{array}$ & $\begin{array}{c}\text { Standard } \\
\text { deviation* }\end{array}$ \\
\hline$m \mu g / m l$ & & $m \mu g / m l$ & \\
$1-9$ & 54 & 6.3 & $\pm 1.5(24 \%)$ \\
$10-19$ & 65 & 15.3 & $\pm 4.0(26 \%)$ \\
$20-29$ & 32 & 24.1 & $\pm 5.1(21 \%)$ \\
$30+$ & 31 & 48.8 & $\pm 7.0(14 \%)$ \\
\hline
\end{tabular}

${ }^{*} \mathrm{SD}=\sqrt{\mathrm{D}^{2} / 2 \mathrm{~N}}(16)$. these studies, and if anything, children had less severe asthma during the hours after hypoglycemia.

Table II lists the pertinent clinical features of the patients and the results of the glucose and GH determinations. It can be seen that most of the children, steroid-treated as well as control subjects, had measurable fasting levels of $\mathrm{GH}$ and that in most the concentration of $\mathrm{GH}$ rose after insulin administration.

In both steroid-treated and control groups very high fasting levels of $\mathrm{GH}$ were occasionally encountered despite the long rest period before collection of initial samples. In some instances, the high values occurred in children who were noted at the time of the test to be particularly apprehensive or upset. Most of the high values were encountered in females. As noted previously and indicated in Table II, the control group contains a much higher ratio of females than the steroid groups, which may account for the higher mean fasting value.

Fig. 3 graphically illustrates the $\mathrm{GH}$ values observed in children during steroid treatment, 
TABLE II

Glucose and GH Values during Insulin Tolerance Tests

\begin{tabular}{|c|c|c|c|c|c|c|c|c|}
\hline \multirow[b]{2}{*}{ Patient } & \multirow[b]{2}{*}{ Age } & \multirow[b]{2}{*}{ Sex } & \multirow[b]{2}{*}{ Steroid* dose } & \multicolumn{3}{|c|}{ Glucose } & \multicolumn{2}{|c|}{ GH } \\
\hline & & & & 0 & Minimum $\ddagger$ & $60 \mathrm{~min} \S$ & Fasting & $60 \mathrm{~min}$ \\
\hline \multicolumn{3}{|c|}{ Nonsteroid-treated control children } & $m g$ & \multicolumn{3}{|c|}{$\mathrm{mg} / 100 \mathrm{ml}$} & \multicolumn{2}{|c|}{$m \mu g / m l$} \\
\hline A. H. & 13 & $\mathrm{M}$ & 0 & 95 & 22 & 53 & 2.5 & 23 \\
\hline G. L. & 13 & M & 0 & 88 & 20 & 42 & 6 & 20 \\
\hline T. L. & 8 & $\mathrm{M}$ & 0 & 94 & 20 & 58 & 1.5 & 7 \\
\hline D. P. & 13.5 & M & 0 & 87 & 19 & 47 & 10 & 27 \\
\hline K. A. & 11 & $\mathrm{~F}$ & 0 & 82 & 26 & 45 & 4 & 54 \\
\hline B. B. & 12 & $\mathrm{~F}$ & 0 & 88 & 37 & 59 & 32.5 & 21 \\
\hline R. C. & 12 & $\mathrm{~F}$ & 0 & 97 & - & 81 & 4.5 & 18 \\
\hline K. H. & 11 & $\mathrm{~F}$ & 0 & 87 & 28 & 78 & 15 & 20 \\
\hline M. R. & 10 & $\mathrm{~F}$ & 0 & 90 & 30 & 67 & 22 & 29 \\
\hline R. S. & 13 & $\mathrm{~F}$ & 0 & 87 & 24 & 38 & 23 & 31 \\
\hline \multicolumn{9}{|c|}{ Children during steroid treatment and $2 \mathrm{wk}$ after steroid withdrawal } \\
\hline M. C. & 15 & M & 15 & 100 & 27 & 72 & 3 & 81 \\
\hline & & & 0 & 93 & 32 & 56 & 1 & 78 \\
\hline S. E. & 9 & M & 10 & 88 & 28 & 64 & 4 & 10 \\
\hline & & & 0 & 89 & 35 & 46 & 10 & 20 \\
\hline M. G. & 9.5 & $\mathrm{M}$ & 10 & 86 & 37 & 72 & 2.5 & 30 \\
\hline & & & 0 & 57 & 28 & 25 & 4.1 & 22 \\
\hline D. G. & 10.5 & $\mathrm{M}$ & 10 & 87 & 27 & 60 & 9 & 15 \\
\hline & & & 0 & 91 & 32 & 53 & 5 & 9 \\
\hline W. I. & 7.5 & M & 7.5 & 79 & 40 & 62 & 12 & 13 \\
\hline & & & 0 & 74 & 22 & 38 & 20 & 18 \\
\hline S. K. & 14 & M & 10 & 95 & 20 & 67 & 7.5 & 30 \\
\hline & & & 0 & 88 & 27 & 61 & 4.1 & 50 \\
\hline B. L. & 12 & $\mathrm{M}$ & 10 & 82 & 52 & 80 & 5.7 & 58 \\
\hline & & & 0 & 87 & 16 & 62 & 5 & 21 \\
\hline J. M. & 11 & $\mathrm{M}$ & 15 & 87 & 43 & 85 & 4 & 14 \\
\hline & & & 0 & 85 & 32 & 57 & 19 & 22 \\
\hline G. P. & 12 & $\mathrm{M}$ & 10 & 89 & 32 & 62 & 6 & 18.5 \\
\hline & & & 0 & 69 & 32 & 38 & 3 & 22 \\
\hline L. C. & 12 & $\mathrm{~F}$ & 10 & 83 & 32 & 77 & 24 & 26 \\
\hline & & & 0 & 85 & 27 & 58 & 1.5 & 22 \\
\hline S. F. & 9 & $\mathrm{~F}$ & 10 & 74 & 30 & 52 & 7 & 12 \\
\hline & & & 0 & 81 & 32 & 36 & 6.5 & 21 \\
\hline B. S. & 12 & $\mathrm{~F}$ & 10 & 97 & 46 & 72 & 3.5 & 29 \\
\hline & & & 0 & 84 & 47 & 66 & 3 & 73 \\
\hline \multicolumn{9}{|c|}{ Children on stable dose steroid } \\
\hline F.G. & 15 & $\mathrm{M}$ & 2.5 & 73 & 28 & 65 & 5 & 46 \\
\hline C. H. & 9 & $\mathrm{M}$ & 5 & 90 & 21 & 62 & 6 & 4 \\
\hline B. K. & 11 & M & 10 & 89 & 32 & 58 & 1 & 20 \\
\hline L. L. & 13 & M & 30 & 98 & 36 & 77 & 8.5 & 12 \\
\hline P. L. & 13 & M & 15 & 86 & 26 & 62 & 14 & 12 \\
\hline D. N. & 11 & M & 10 & 78 & & & 10.5 & 11 \\
\hline R. R. & 15 & M & 10 & 88 & 31 & 61 & 1 & 25 \\
\hline J. S. & 13 & M & 20 & 83 & 32 & 71 & 11 & 22 \\
\hline C. B. & 13 & $\mathrm{~F}$ & 5 & 100 & 29 & 56 & 9 & 5.8 \\
\hline D. B. & 15 & $\mathrm{~F}$ & 10 & 78 & 42 & 55 & 14 & 15 \\
\hline I. G. & 12 & $\mathrm{~F}$ & 5 & 81 & 35 & 54 & 24 & 19 \\
\hline
\end{tabular}

* Daily dose of prednisone.

$\ddagger$ Minimum refers to minimum plasma concentration after insulin.

$\S 60 \mathrm{~min}$ refers to glucose and $\mathrm{GH}$ concentration $60 \mathrm{~min}$ after insulin. 


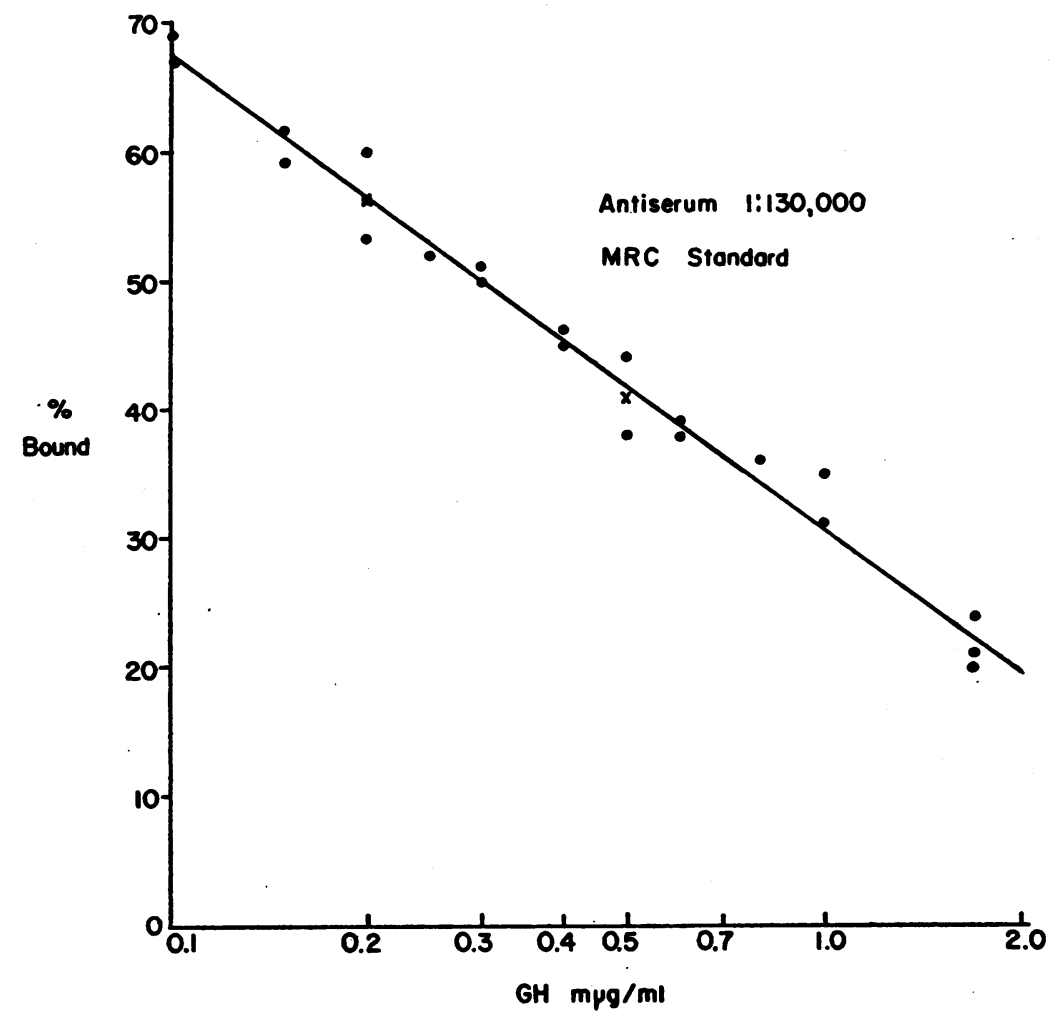

FIGURE 2 Growth hormone immunoassay standard curve (2/9/66). The same data shown in Fig. 1 are plotted as per cent of bound radioactive label vs. $\log$ $\mathrm{GH}$ concentration in $\mathrm{m} \mu \mathrm{g} / \mathrm{ml}$.

shortly after steroid withdrawal, and in control subjects. Although there was considerable variability, the mean concentrations and range of values were quite similar in the three groups both during the fasting state and after induced hypoglycemia. (Mean fasting $\mathrm{GH}$ concentration : control $=12.1$ $\mathrm{m} \mu \mathrm{g} / \mathrm{ml}$; steroid-treated $=8.4 \mathrm{~m} \mu \mathrm{g} / \mathrm{ml}$; steroidwithdrawn $=6.9 \mathrm{~m} \mu \mathrm{g} / \mathrm{ml}$. Mean postinsulin $\mathrm{GH}$ concentration : control $=25 \mathrm{~m} \mu \mathrm{g} / \mathrm{ml}$; steroidtreated $=23 \mathrm{~m} \mu \mathrm{g} / \mathrm{ml}$; steroid-withdrawn $=31.4$ $\mathrm{m} \mu \mathrm{g} / \mathrm{ml}$.). In each of the groups the rise in plasma GH concentration after insulin administration was significant $(P=0.01-0.05)$. The postinsulin values in the steroid-treated children showed more variability than that observed in either of the control groups. With the exception of the two lowest postinsulin values (observed in patients who were in the stable dose steroid group and who received a small dose of prednisone on the morning of the study), the distribution of values was similar in children who subsequently tolerated withdrawal of steroid and those who did not.
Fig. 4 compares the GH concentrations in individual children who were studied while receiving a large dose of prednisone and again 2 wk after corticosteroid withdrawal. The similarity of values is further shown by the data in Table III which lists the GH concentrations observed in several children who were studied serially while steroid dosage was being reduced and at intervals after total withdrawal of corticosteroid. It can be seen that the GH values for each individual child were fairly reproducible and that there was no consistent trend in either fasting or postinsulin values in relation to discontinuation of steroids.

Table IV summarizes the results of statistical comparison of the glucose and $\mathrm{GH}$ values observed in the different groups of children. There were no significant differences in $\mathrm{GH}$ values in children recently withdrawn from steroid compared with control children who had not received steroid for many months. The standard dose of insulin $(0.1 \mathrm{U} / \mathrm{kg})$ produced significantly lower minimum and $60-\mathrm{min}$ blood sugars in contol sub- 
Fasting

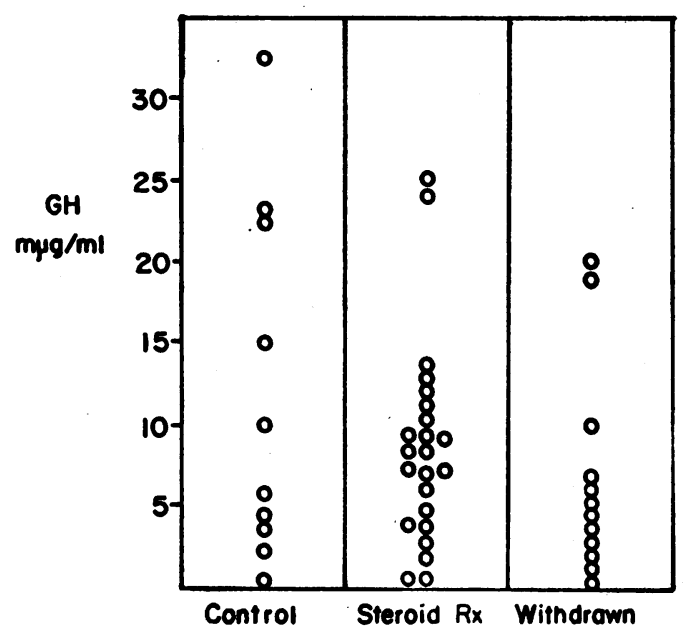

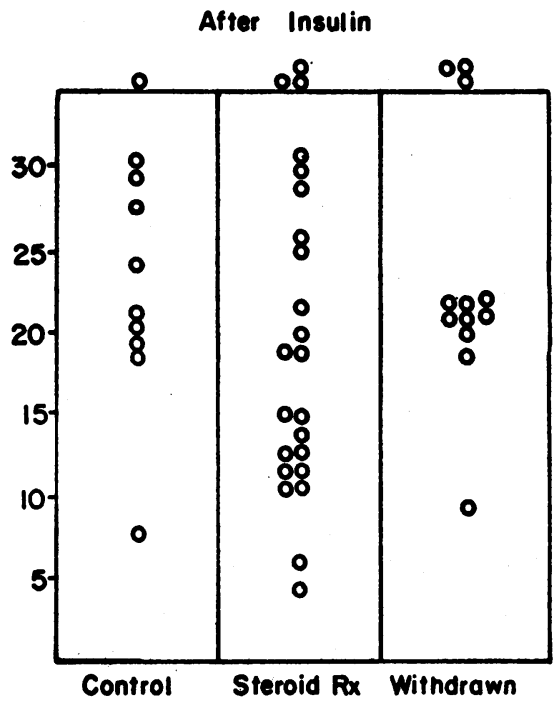

FigURE 3 Plasma GH concentrations in control and steroid-treated children. Each open circle represents a single patient.

jects than those observed in children who were receiving steroid therapy $(P=<0.05)$. Despite the differences in degree and duration of hypoglycemia, there was no significant difference in mean $\mathrm{GH}$ values during either the fasting state or after insulin administration in steroid-treated and control children (fasting GH $P=0.2$; post-insulin GH $P=0.65$ ). Similarly, comparison of the results observed when the same subjects were studied during steroid therapy and shortly after steroid withdrawal again revealed no significant differences in $\mathrm{GH}$ values $(P=0.60-0.85)$, despite the fact that during the poststeroid withdrawal period the duration of hypoglycemia was significantly greater $(P=<0.001$ for blood glucose at $60 \mathrm{~min}$ ).

The GH value at $60 \mathrm{~min}$ after insulin administration was used as the index of response to hypoglycemia in comparing the various groups of subjects, since this value was measured in all studies and most subjects exhibited maximum $\mathrm{GH}$ concentration at this time. Data at later points after insulin administration are less complete, since a number of studies were terminated
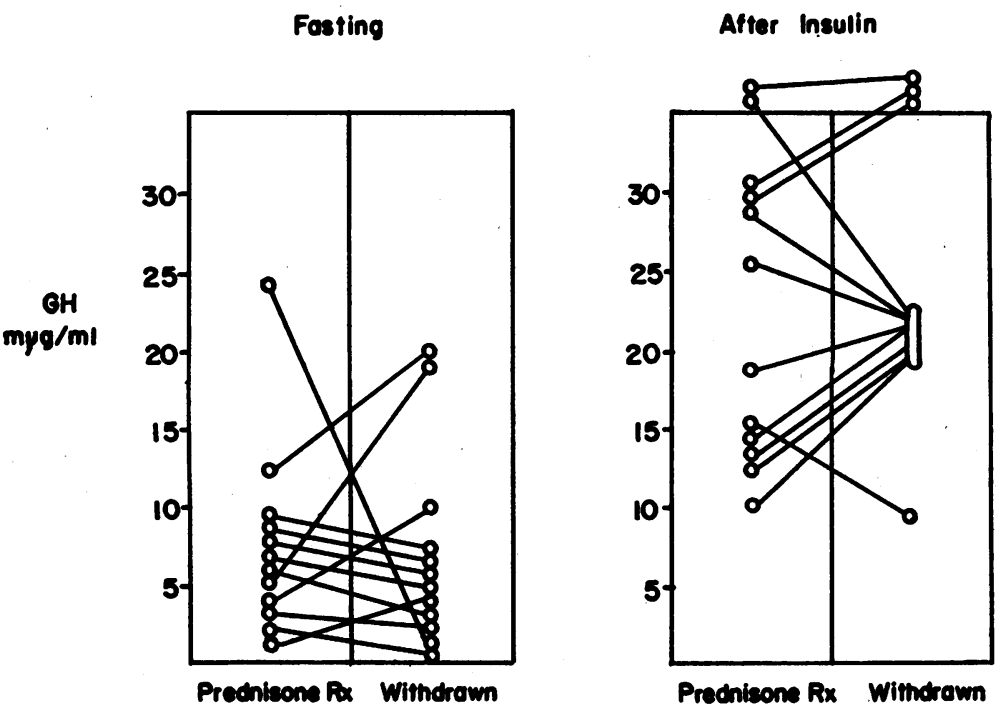

FIGURE 4 Plasma GH levels in individual children during steroid treatment and 2 wk after steroid withdrawal. The connecting bars identify the $\mathrm{GH}$ values observed in each child during treatment and after steroid withdrawal. 
TABLE III

GH Levels during Prednisone Therapy and after Withdrawal

\begin{tabular}{|c|c|c|c|c|c|c|c|}
\hline & \multicolumn{4}{|c|}{ Daily prednisone dosage } & \multicolumn{3}{|c|}{ Duration of withdrawal } \\
\hline & $15 \mathrm{mg}$ & $10 \mathrm{mg}$ & $5 \mathrm{mg}$ & $2.5 \mathrm{mg}$ & $2 \mathrm{wk}$ & $6 \mathrm{wk}$ & $10 \mathrm{wk}$ \\
\hline \multicolumn{8}{|l|}{ Patient } \\
\hline L. C. & & $\begin{array}{l}24^{*} \\
26 \ddagger\end{array}$ & & $\begin{array}{r}4 \\
15\end{array}$ & $22^{1.5}$ & $\begin{array}{r}3 \\
15\end{array}$ & $\begin{array}{l}11 \\
21\end{array}$ \\
\hline M. G. & & $\begin{array}{l}2.5 \\
30\end{array}$ & & $\begin{array}{l}3.1 \\
26\end{array}$ & $\begin{array}{l}4.1 \\
22\end{array}$ & & \\
\hline D. G. & & $\begin{array}{r}9 \\
15\end{array}$ & & $\begin{array}{c}5.5 \\
15\end{array}$ & $\begin{array}{l}5 \\
9\end{array}$ & & $\begin{array}{r}2 \\
14\end{array}$ \\
\hline J. M. & $\begin{array}{r}4 \\
14\end{array}$ & $\begin{array}{r}4 \\
23\end{array}$ & & $\begin{array}{l}2.6 \\
42\end{array}$ & $\begin{array}{l}19 \\
22\end{array}$ & $\begin{array}{c}9.5 \\
21\end{array}$ & \\
\hline M. C. & $\begin{array}{r}3 \\
81\end{array}$ & & & & $\begin{array}{r}1 \\
78\end{array}$ & $\begin{array}{r}3 \\
127\end{array}$ & $\begin{array}{c}4.5 \\
113^{4}\end{array}$ \\
\hline
\end{tabular}

* Upper number of each pair $=$ fasting $\mathrm{GH}$ value.

$\ddagger$ Lower number of each pair $=$ value after insulin.

before $2 \mathrm{hr}$ because of persistent symptoms of group. While most subjects showed a beginning hypoglycemia. However, available specimens re- decrease in GH concentration, there were a few vealed that mean $\mathrm{GH}$ concentrations at $90 \mathrm{~min}$ subjects in each group who showed a further rise were similar to those observed at $60 \mathrm{~min}$ in each in GH level at $90 \mathrm{~min}$. By $120 \mathrm{~min}$ the GH con-

TABLE IV

Statistical Comparison of Plasma Glucose and Growth Hormone Concentrations in Steroid-Treated and Control Patients

\begin{tabular}{|c|c|c|c|c|c|c|}
\hline & \multicolumn{3}{|c|}{ Mean glucose } & \multicolumn{3}{|c|}{ Mean GH } \\
\hline Recent steroi & \multicolumn{2}{|c|}{$\begin{array}{l}m \mathrm{mg} / 100 \mathrm{ml} \\
\text { thdrawal vs. control }\end{array}$} & & \multicolumn{3}{|c|}{$m \mu g / m l$} \\
\hline & $\begin{array}{l}\text { Steroid withdrawal } \\
\qquad(n=12)\end{array}$ & $\begin{array}{l}\text { Control } \\
(n=10)\end{array}$ & & $\begin{array}{l}\text { Steroid withdrawal } \\
\quad(n=12)\end{array}$ & $\begin{array}{l}\text { Control } \\
(n=10)\end{array}$ & \\
\hline $\begin{array}{l}\text { Fasting } \\
\text { Minimum* }\end{array}$ & $\begin{array}{l}81.9 \pm 10.4 \\
30.2 \pm 7.5\end{array}$ & $\begin{array}{l}89.5 \pm 4.5 \\
25.1 \pm 5.8\end{array}$ & $\begin{array}{l}P=0.05 \\
P=0.11\end{array}$ & $6.9 \pm 6.3$ & $12.1 \pm 10.6$ & $P=0.15$ \\
\hline $60 \min \ddagger$ & $49.7 \pm 12.8$ & $56.8 \pm 14.8$ & $P=0.25$ & $31.4 \pm 22.7$ & \pm 12.2 & $P=0.45$ \\
\hline
\end{tabular}

Steroid-treated vs. control

$\begin{array}{lcccccc} & \begin{array}{c}\text { Steroid-treated } \\ (n=23)\end{array} & \begin{array}{c}\text { Control } \\ (n=10)\end{array} & \begin{array}{c}\text { Steroid-treated } \\ (n=23)\end{array} & \begin{array}{c}\text { Control } \\ (n=10)\end{array} \\ \text { Fasting } & 86.6 \pm 7.6 & 89.5 \pm 4.5 & P=0.3 & 8.4 \pm 6 & 12.1 \pm 10.6 & P=0.2 \\ \text { Minimum } & 33 \pm 7.7 & 25.1 \pm 5.8 & P=0.02 & & & \\ 60 \text { min } & 65.7 \pm 8.8 & 56.8 \pm 14.8 & P=0.04 & 23 \pm 17.4 & 25 \pm 12.2 & P=0.75\end{array}$

Same children during steroid treatment and after steroid withdrawal

\begin{tabular}{|c|c|c|c|c|c|c|}
\hline & $\begin{array}{l}\text { On steroid } \\
(n=12)\end{array}$ & $\begin{array}{l}\text { Off steroid } \\
(n=12)\end{array}$ & & $\begin{array}{l}\text { On steroid } \\
(n=12)\end{array}$ & $\begin{array}{l}\text { Off steroid } \\
(n=12)\end{array}$ & \\
\hline Fasting & $87.2 \pm 7.5$ & $81.9 \pm 10.4$ & $P=0.17$ & $7.4 \pm 5.9$ & $6.9 \pm 6.3$ & $P=0.85$ \\
\hline Minimum & $34.5 \pm 9.3$ & $30.2 \pm 7.5$ & $P=0.23$ & & & \\
\hline $60 \mathrm{~min}$ & $68.8 \pm 9.3$ & $49.7 \pm 12.8$ & $P=0.001$ & \pm 21.3 & $31.4 \pm 22.7$ & $P=0.6$ \\
\hline
\end{tabular}

* Minimum refers to minimum plasma glucose concn after insulin.

$\ddagger 60 \mathrm{~min}$ refers to glucose and $\mathrm{GH}$ concentrations $60 \mathrm{~min}$ after insulin. 
centrations were approaching preinsulin levels and again were higher in control subjects than in corticosteroid-treated or withdrawn groups. At 90 and 120 min blood glucose was similar in control and steroid-treated children but continued to be lower in subjects recently withdrawn from steroid.

\section{DISCUSSION}

Corticosteroid inhibition of pituitary GH release has been reported in adults and postulated as the mechanism responsible for growth inhibition in steroid-treated children (2). In the present study, plasma $\mathrm{GH}$ concentrations were measured in 33 asthmatic children including 23 who had received prolonged corticosteroid therapy. The data indicate that corticosteroid-treated children secrete growth hormone and maintain plasma GH concentrations which are similar to those of nonsteroidtreated control subjects, both during the fasting state and after induced hypoglycemia. $\mathrm{GH}$ values in individual children studied during therapy and after steroid withdrawal were found to be fairly reproducible and showed no differences in relation to corticosteroid administration. The plasma growth hormone concentrations reported here are similar to the values which have been observed in other children (17-19).

The protocol used in the present study differed from those used by other investigators $(2,3)$ for studying corticosteroid-treated subjects. In contrast to previous studies $(2,3)$ in which plasma $\mathrm{GH}$ response to induced hypoglycemia was evaluated within 1-2 hr after corticosteroid administration, most of the present studies were performed approximately $12-16 \mathrm{hr}$ after the last dose of steroid (prednisone). Our data therefore provide no information about the acute effects of corticosteroid on pituitary function. However, the data clearly indicate that prolonged suppression of pituitary GH release does not occur in the steroidtreated children. Since maintenance corticosteroid therapy is usually administered within an 8-12 hr daytime period and allows a 12-16 $\mathrm{hr}$ interval between the last evening dose and the first morning dose, our results suggest that corticosteroidtreated children are capable of maintaining normal plasma $\mathrm{GH}$ levels during a considerable portion of the day.

The demonstration of normal plasma GH levels in children receiving therapy in doses known to be associated with growth retardation $(20,21)$ argues against deficiency of $\mathrm{GH}$ as the primary mechanism responsible for dwarfism. Similar studies have shown that children with other nonpituitary forms of dwarfism also have normal levels of $\mathrm{GH}$ during fasting and after hypoglycemia (17-19). However it is recognized that pituitary release of $\mathrm{GH}$ in response to an artificial, severe hypoglycemic stimulus may not be comparable to $\mathrm{GH}$ release under more normal conditions. It still remains to be demonstrated whether the mean daily plasma concentration to which tissues are exposed is similar in corticosteroid and other dwarfed children as compared with normal controls.

It was of interest that the mean $\mathrm{GH}$ values were similar in steroid-treated and control children despite significant differences in degree and duration of hypoglycemia. It has been shown in adults that small doses of insulin may not produce sufficient hypoglycemia to cause maximal release of pituitary GH $(2,22)$. On the other hand, the data presented by Greenwood, Landon, and Stamp suggest that there is a maximal stimulus, above which greater degree or duration of hypoglycemia does not result in further rise in plasma GH concentration (22). The results of the present study suggest that the degree of hypoglycemia achieved in the steroid-treated subjects is sufficient to cause maximal release of $\mathrm{GH}$ in most children, and that more severe hypoglycemia represents a supramaximal stimulus. It is possible, however, that the lower postinsulin GH values observed in some steroid-treated children are related to the lesser degree of hypoglycemia in this group.

The current study further emphasizes the difference in magnitude of $\mathrm{GH}$ levels in children as compared with adults. Adults have low fasting levels of $\mathrm{GH}(<5 \mathrm{m \mu g} / \mathrm{ml})$ and show a brisk response to hypoglycem:a with postinsulin $\mathrm{GH}$ values of $>40 \mathrm{~m} \mu \mathrm{g} / \mathrm{ml} \mathrm{(23).} \mathrm{In} \mathrm{contrast} \mathrm{the} \mathrm{children} \mathrm{in}$ this study, as well as those reported by other investigators $(17-19)$, have higher fasting levels of GH $(6-8 \mathrm{~m} \mu \mathrm{g} / \mathrm{ml})$ and show a smaller magnitude of rise in GH level $(15-30 \mathrm{~m} \mu \mathrm{g} / \mathrm{ml})$ after hypoglycemia. Data reported by Cornblath, Parker, Reisner, Forbes, and Daughaday have shown that young infants have even higher fasting $\mathrm{GH}$ levels $(15-60 \mathrm{~m} \mu \mathrm{g} / \mathrm{ml})(24)$. These studies indicate that plasma GH levels can be expected to vary with age 
and suggest that some of the mechanisms that control pituitary GH release may be different in children and in adults.

\section{ACKNOWLEDGMENTS}

The authors gratefully acknowledge the help and advice of Dr. C. J. Falliers, C. J. Hlad, and Dr. David W. Talmage.

This work was supported by a V.A. Clinical Investigatorship and by a U. S. Public Health Service Research grant HD-02248. Dr. Morris is a V.A. Clinical Investigator.

\section{REFERENCES}

1. Morris, H. G., J. R. Jorgensen, H. Elrick, and R. E. Goldsmith. 1968. Metabolic effects of human growth hormone in corticosteroid-treated children. J. Clin. Invest. 47: 436.

2. Frantz, A. G., and M. T. Rabkin. 1964. Human growth hormone, clinical measurement, response to hypoglycemia, and suppression by corticosteroids. New Engl. J. Med. 271: 1375.

3. Hartog, M., M. A. Gaafar, and R. Fraser. 1964. Effect of corticosteroids on serum growth hormone. Lancet. 2: 376.

4. Cawley, L. P., F. E. Spear, and R. Kendall. 1959. Ultramicro chemical analysis of blood glucose with glucose oxidase. Am. J. Clin. Pathol. 32: 195.

5. Fingerhut, B., R. Ferzola, and W. H. Marsh. 1963. Application of a ferrocyanide phosphomolybdate reaction to an automated determination of serum glucose. Clin. Chim. Acta. 8: 953.

6. Glick, S. M., J. Roth, R. S. Yalow, and S. A. Berson. 1963. Immunoassay of human growth hormone in plasma. Nature. 199: 784.

7. Fisher, R. A. 1954. Statistical Methods for Research Workers. Hafner Publishing Co., Inc., New York. 12 th edition.

8. Greenwood, F. C., W. M. Hunter, and J. S. Glover. 1963. The preparation of ${ }^{181} \mathrm{I}$-labelled human growth hormone of high specific radioactivity. Biochem. J. 89: 114.

9. Smithies, O. 1955. Zone electrophoresis in starch gel: group variation in serum proteins of normal human adults. Biochem. J. 61: 629 .

10. Reisfeld, R. A., B. G. Hallows, D. E. Williams, N. G. Brink, and S. L. Steelman. 1963. Purification of human growth hormone on "Sephadex G-200." Nature. 197: 1206.

11. Yalow, R. S., and S. A. Berson. 1960. Immunoassay of endogenous plasma insulin in man. J. Clin. Invest. 39: 1157 .
12. Elrick, H., V. Yearwood-Drayton, Y. Arai, F. Leaver, and H. G. Morris. 1963. Collection, processing and fractionation of human pituitary glands. J. Clin. Endocrinol. Metab. 23: 694.

13. Hartog, M., M. A. Gaafar, B. Meisser, and R. Fraser. 1964. Immunoassay of serum growth hormone in acromegalic patients. Brit. Med. J. 2: 1229.

14. Hunter, W. M., and F. C. Greenwood. 1964. A Radioimmunoelectrophoretic assay for human growth hormone: Biochem. J. 91: 43.

15. Frantz, A. G., and M. T. Rabkin. 1965. Effects of estrogen and sex difference on secretion of human growth hormone. J. Clin. Endocrinol. Metab. 25: 1470.

16. Brown, J. B., B. Bulbrook, and F. C. Greenwood. 1957. An evaluation of a chemical method for the estimation of oestriol, oestrone, and oestradiol-17B in human urine. J. Endocrinol. 16: 41.

17. Kaplan, S. L., C. A. L. Abrams, J. J. Bell, F. A. Conte, and M. M. Grumbach. 1965. Serum growth hormone response to insulin-induced hypoglycemia in disorders of growth. Sixth Pan-American Congress of Endocrinology. (Abstr. No. 152)

18. Root, A. W., R. L. Rosenfield, A. M. Bongiovanni, and W. R. Eberlein. 1967. The plasma growth hormone response to insulin-induced hypoglycemia in children with retardation of growth. Pediatrics 39: 844 .

19. Stimmler, L., and G. A. Brown. 1967. Growth hormone secretion provoked by insulin-induced hypoglycaemia in children of short stature. Arch. Disease Childhood 42: 232.

20. Blodgett, F. M., L. Burgin, D. Iezzoni, D. Gribetz, and N. B. Talbot. 1956. Effects of prolonged cortisone therapy on the statural growth, skeletal maturation and metabolic status of children. New Engl. J. Med. 254: 636.

21. Falliers, C. J., L. S. Tan, J. Szentivanyi, J. R. Jorgensen, and S. C. Bukantz. 1963. Childhood asthma and steroid therapy as influences on growth $\mathrm{Am}$. J. Diseases Children. 105: 127.

22. Greenwood, F. C., J. Landon, and T. C. B. Stamp. 1966. The plasma sugar, free fatty acid, cortisol and growth hormone response to insulin. I. In control subjects. J. Clin. Invest. 45 : 429.

23. Roth, J., S. M. Glick, R. S. Yalow, and S. A. Berson. 1963. Secretion of human growth hormone: physiologic and experimental modification. Metab. Clin. Exptl. 12: 577.

24. Cornblath, M., M. L. Parker, S. H. Reisner, A. E. Forbes, and W. H. Daughaday. 1965. Secretion and metabolism of growth hormone in premature and fullterm infants. J. Clin. Endocrinol. Metab. 25: 209. 